Background: Our previous results showed that in retinas from streptozotocin (STZ)-induced diabetic rats there is an increased level of interleukin-1 $\beta$ (IL1 $\beta$ ). This cytokine may be involved in the expression of the inducible isoform of the nitric oxide synthase (iNOS), with consequent synthesis of large amounts of NO and blood-retinal barrier (BRB) breakdown.

Aims: The aim of this work was to examine whether the administration of cyclosporin-A (Cs-A) to STZinduced diabetic rats inhibits the synthesis of IL-1 $\beta$ and the expression of the inducible proteins, iNOS and cyclo-oxygenase-2 (COX-2) in retinal cells, and whether the activity of these proteins contribute to BRB breakdown.

Methods: The level of IL-1 $\beta$ was evaluated by ELISA and the NO production by $\mathrm{L}$ - $\left\{{ }^{3} \mathrm{H}\right\}$-citrulline formation. Expression of iNOS and COX-2 proteins was determined by two methods, western blot and immunohistochemistry. The permeability of the BRB was assessed by quantification of the vitreous protein.

Results and discussion: Our results indicated that the levels of IL-1 $\beta$ and NO in retinas from Cs-A-treated diabetic rats are significantly reduced, as compared to that in non-treated diabetic rats. The treatment of diabetic rats with Cs-A also significantly inhibited the expression of the inducible proteins, iNOS and COX2. The evaluation of the vitreous protein content revealed that Cs-A also reduces the BRB permeability. Taken together, these results suggest that the increased production of the inflammatory mediators, IL-1 $\beta$ and NO, in diabetes may affect the BRB permeability and therefore contribute to the development of diabetic retinopathy.

Key words: Blood-retinal barrier (BRB), Nitric oxide, Interleukin-1 $\beta$ (IL-1 $\beta$ ), cyclosporin-A (Cs-A)

\section{Effect of cyclosporin-A on the blood-retinal barrier permeability in streptozotocin-induced diabetes}

\author{
Anália Carmo, ${ }^{1}$ José G. Cunha-Vaz, ${ }^{1}$ \\ Arsélio P. Carvalho ${ }^{2}$ and Maria Celeste Lopes ${ }^{2, C A}$
}

${ }^{1}$ Center of Ophthalmology, Institute for Biomedical Research on Light and Image, University of Coimbra, Coimbra, Portugal; ${ }^{2}$ Center for

Neurosciences of Coimbra, Department of Zoology, University of Coimbra, Coimbra, Portugal

\author{
${ }^{\mathrm{CA}}$ Corresponding Author \\ Tel: 351239480237 \\ Fax: 351239480217 \\ Email: mcflopes@imagem.ibili.uc.pt
}

\section{Introduction}

Homeostasis in the retina is regulated by the bloodretinal barrier (BRB) which, among other physiological functions, restricts the movement of molecules and minimizes leukocyte migration into the retina. ${ }^{1,2}$ In diabetic retinopathy, the integrity of the $\mathrm{BRB}$ is altered, ${ }^{1,3,4}$ which leads to visual loss by mechanisms that are not well understood.

Results from our previous work suggested that in streptozotocin (STZ)-induced diabetic rats the increased BRB permeability may be the consequence of an increased expression of the inducible isoform of the enzyme nitric oxide synthase (iNOS)..$^{5}$ In addition we also found that, in retinas from diabetic rats, there was an increased level of interleukin-1 $\beta$ (IL-1 $\beta$ ) and prostaglandin E2 (PGE2). ${ }^{6,7}$ These findings are in agreement with other studies showing that IL-1 $\beta$ induces the expression of iNOS and of cyclo-oxygenase-2 (COX-2) in $\beta$-cells from Langerhans islets of diabetic animals, leading to cell death and to islet destruction. ${ }^{8,9}$ It was also observed that an intraocular injection of IL-1 $\beta$ in Wistar rats causes disruption of the $\mathrm{BRB}^{10}$ and in the $\mathrm{BB} /$ Edinburgh rats, an animal model of insulin-dependent diabetes, cyclosporin A (Cs-A) reduces $\beta$ cell destruction and prevents the development of diabetes. ${ }^{11}$

In this work, Cs-A, an anti-inflammatory drug that inhibits IL-1 $\beta$ production, ${ }^{12}$ was used to investigate whether the increase of IL-1 $\beta$ synthesis that occurs in STZ-induced diabetic rats modulates both the expression of the inducible proteins iNOS and COX-2 in the retinal cells and the BRB permeability.

\section{Material and methods}

\section{Chemicals}

STZ $(60 \mathrm{mg} / \mathrm{ml} / \mathrm{kg})$ and the kit for protein quantification were purchased from Sigma Chemical Co., St Louis, USA. Cs-A $(10 \mathrm{mg} / \mathrm{kg} /$ day $)$ was from Sandoz and the kit for quantification of Cs-A was from Abbott Laboratories (Lisboa, Portugal). The kit for IL-1 $\beta$ quantification was purchased from $R \& D$ Systems, 
Oxon, UK. L- $\left[{ }^{3} \mathrm{H}\right]$-arginine was purchased from Amersham, Bucks, UK. Dowex AG 50W-X8 was obtained from BioRad, Herts, UK. The kit for glucose quantification was purchased from Boheringer, East Sussex, UK. The antibody anti-iNOS was purchased from Transduction Laboratories, Lexington KY, USA and the antibody anti-COX 2 was from Santa Cruz, CA, USA. The antibody anti-actin was from Boheringer, East Sussex, UK. The secondary antibodies anti-rabbit and anti-rat were from Dako, Copenhagen, Denmark and the antigoat was from Boheringer, East Sussex, UK. All other chemicals used in this study were of analytical grade.

\section{Animals}

Twenty male Wistar rats (250-300g body weight) were anesthetized with ether and injected peritoneally with a freshly prepared solution of STZ $(60 \mathrm{mg} /$ $\mathrm{ml} / \mathrm{kg}$ in $0.1 \mathrm{M}$ citrate buffer, $\mathrm{pH}=4.5)$, ten of them started treatment with Cs-A $(10 \mathrm{mg} / \mathrm{kg} / \mathrm{day})$ on the same day. Twenty normal rats were injected with an equal volume of $0.1 \mathrm{M}$ citrate buffer and ten of them also started treatment with Cs-A $(10 \mathrm{mg} / \mathrm{kg} / \mathrm{day})$.

All animals were assessed regularly for weight, blood glucose and glycosuria. The blood glucose levels were checked with a colorimetric method based on a standard method, and glycosuria was assessed with glucose oxidase reagent strips. The criteria for diabetes were persistent hyperglycemia ( $>350 \mathrm{mg} / 100 \mathrm{ml}$ ), glycosuria, polyuria and impaired growth according to the results previously obtained. ${ }^{4}$

The Cs-A-treated animals were also assessed daily for blood Cs-A which was determined according to the kit instructions.

Eight days after the induction of diabetes the animals were anesthetized, the eyes were removed and the retinas peeled off without the retinal pigment epithelium. Since the development of the retinal alterations due to diabetes is not symmetrical each eye was analysed independently. For each experiment five normal rats, five Cs-A-treated normal rats, five diabetic rats and five Cs-A-treated diabetic rats were used.

In all the experiments the animals were treated according to the statements of the 'Association for Research in Vision and Ophthalmology.'

\section{Assay for IL-1 $\beta$ measurement}

To quantify the retinal levels of IL-1 $\beta$ the retinas were washed and sonicated in the diluent calibrator of the kit. The level of IL-1 $\beta$ was then determined by ELISA according to the kit instructions.

\section{Measurement of nitric oxide synthase activity}

To determine the NOS activity the retinas were washed and sonicated in HEPES buffer $(20 \mathrm{mM}, \mathrm{pH}=$ 7.4). The NOS activity was determined in the retinal lysates by measuring the formation of $\mathrm{L}-\left[{ }^{3} \mathrm{H}\right]$-citrulline from L- $\left[{ }^{3} \mathrm{H}\right]$-arginine, as previously described. ${ }^{5}$ Briefly, retinal lysates $(0.5 \mathrm{mg}$ protein $/ \mathrm{ml})$ were incubated for $30 \mathrm{~min}$, at $37^{\circ} \mathrm{C}$, in a total volume of $200 \mu \mathrm{l}$ of an incubation medium containing $0.5 \mathrm{mM}$ NADPH, $2 \mathrm{mM} \mathrm{Ca}{ }^{2+}, 1 \mathrm{mM}$ EGTA and $10 \mathrm{nM} \mathrm{L-}\left[{ }^{3} \mathrm{H}\right]$-arginine $(60 \mathrm{Ci} / \mathrm{mmol})$. The enzymatic reactions were initiated by addition of retinal lysates to the incubation medium and the assays were terminated using $1.8 \mathrm{ml}$ of STOP solution ( $50 \mathrm{mM}$ HEPES, $\mathrm{pH} 5.5,5 \mathrm{mM}$ EDTA, at $\left.4^{\circ} \mathrm{C}\right)$. The $\mathrm{L}-\left[{ }^{3} \mathrm{H}\right]$ - citrulline was separated from L- $\left[{ }^{3} \mathrm{H}\right]$-arginine on Dowex AG 50W-X8 $\left(\mathrm{Na}^{+}\right.$ form) columns previously equilibrated with STOP solution. The L- $\left[{ }^{3} \mathrm{H}\right]$-citrulline was eluted with $2 \mathrm{ml}$ of distilled water, and the radioactivity was quantified by liquid-scintillation counter.

\section{Western blot analysis}

For immunodetection of iNOS and COX-2, retinas were sonicated in $200 \mu \mathrm{l}$ of lysis buffer (phosphate-buffered saline containing $10 \mathrm{mM}$ EDTA, 1\% Triton X-100 and the protease inhibitor cocktail). In brief, protein samples ( $25 \mu \mathrm{g}$ protein of retinal lysate) were separated on a $10 \%$ sodium dodecyl sulfate-polyacrylamide gel electrophoresis and transferred to a polyvinylidene difluoride membrane. The membrane was blocked with 5\% dry milk in Tris-buffered saline with $0.1 \%$ Tween 20 (TBST) for $1 \mathrm{~h}$. The levels of iNOS protein were detected using a 1:2000 dilution of a rabbit polyclonal anti-mouse iNOS antibody for $1 \mathrm{~h}$, followed by incubation with a 1:1000 dilution of the horseradish peroxidase-conjugated anti-rabbit antibody for $1 \mathrm{~h}$. The levels of COX-2 were determined using a 1:500 dilution of goat polyclonal anti-rat COX-2 antibody for $1 \mathrm{~h}$, followed by incubation with a 1:1000 dilution of horseradish peroxidase-conjugated anti-goat antibody for $1 \mathrm{~h}$. The immunocomplexes were visualized by the ECL chemiluminiscence method. Subsequently, the relative expression of iNOS was analysed by a computer program (Adobe Photoshop, IBM) and a densitometric analysis was performed using the ImageQuant software (Molecular Dynamics Inc., Sunnyvale, CA). To ensure that the loading of protein was equivalent, the membranes were stripped and reprobed with anti-actin antibody (1:10000).

\section{Immunohistochemical localization of iNOS}

For immunohistochemical detection of iNOS, the animals were killed and the eyes removed and fixed for $24 \mathrm{~h}$ in $4 \%$ paraformaldehyde in $0.1 \mathrm{M} \mathrm{Na}$ phosphate buffer, $\mathrm{pH} 7.4$ at $4^{\circ} \mathrm{C}$. Eyes were then dehydrated through a graded series of alcohols, embedded in paraffin and $5-\mu \mathrm{m}$ thick sections were cut.

Immunohistochemistry was performed on sections pre-incubated in phosphate-buffer saline containing normal rabbit serum (1:20). For localization of iNOS, 
eye sections were incubated for $2 \mathrm{~h}$ at room temperature with polyclonal anti-iNOS $(2.5 \mu \mathrm{g} / \mathrm{ml})$ diluted in phosphate-buffer saline and then incubated for $45 \mathrm{~min}$ at room temperature with fluorescein swine anti-rabbit $(1: 20)$ diluted in phosphate-buffer saline. Control procedures included the study of eye sections without the primary antibody.

\section{Evaluation of BRB permeability}

The permeability of BRB was measured by quantification of the vitreous protein concentration according to the method described by Berkowitz and coworkers. $^{13}$ Briefly, the eyes were removed and vitreous samples dissected into $10 \mathrm{mM}$ phosphatebuffer saline. After the removal of the samples they were frozen at $-70^{\circ} \mathrm{C}$. On the day of protein measurement, the vitreous was thawed to room temperature, sonicated and centrifuged for $30 \mathrm{~min}$ at $10,000 \mathrm{~g}$. Protein levels were measured, using the Sigma protein assay kit with $25 \mu$ l of sample in $200 \mu 1$ of assay reagent for $30 \mathrm{~min}$ at $37^{\circ} \mathrm{C}$, before reading the absorbance at $550 \mathrm{~nm}$. Protein concentrations were determined using the Sigma protein assay kit, and standards of albumin. The vitreous from all rats was weighted to determine whether it had been losing water due to the hyperosmolarity developed by hyperglycemia, but no differences were found.

\section{Statistics}

All data are presented as mean \pm SD of at least five separate experiments. Statistical analyses was performed using one-way ANOVA analysis and Dunnett's test. The confidence interval was $95 \%$.

\section{Results}

\section{Effect of Cs-A on IL-1 $\beta$ concentration}

Eight days after the induction of diabetes by STZ all the diabetic animals, treated and non-treated with CsA, developed hyperglycemia (above $350 \mathrm{mg} / 100 \mathrm{ml}$ ), increased polyuria and decreased body weight. In both types of animals, normal rats treated and nontreated with Cs-A, the glycemia was lower than $95 \mathrm{mg} / 100 \mathrm{ml}$.

Quantification of the Cs-A concentration in serum and in retinas showed that in normal and diabetic rats treated with Cs-A, the serum concentration of Cs-A was higher than $1500 \mathrm{ng} / \mathrm{ml}$ and the retinal concentration of Cs-A was higher than $200 \mathrm{ng} / \mathrm{ml}$, which have been considered therapeutical levels. ${ }^{14}$

As indicated in Fig. 1 the levels of IL-1 $\beta$ in retinal lysates from Cs-A-treated diabetic rats were significantly reduced $(0.17 \pm 0.014 \mathrm{pg} / \mathrm{mg}$ protein $)$ compared to those in non-treated Cs-A diabetic rats $(0.31 \pm 0.08 \mathrm{pg} / \mathrm{mg}$ protein $), p<0.05$. The level of

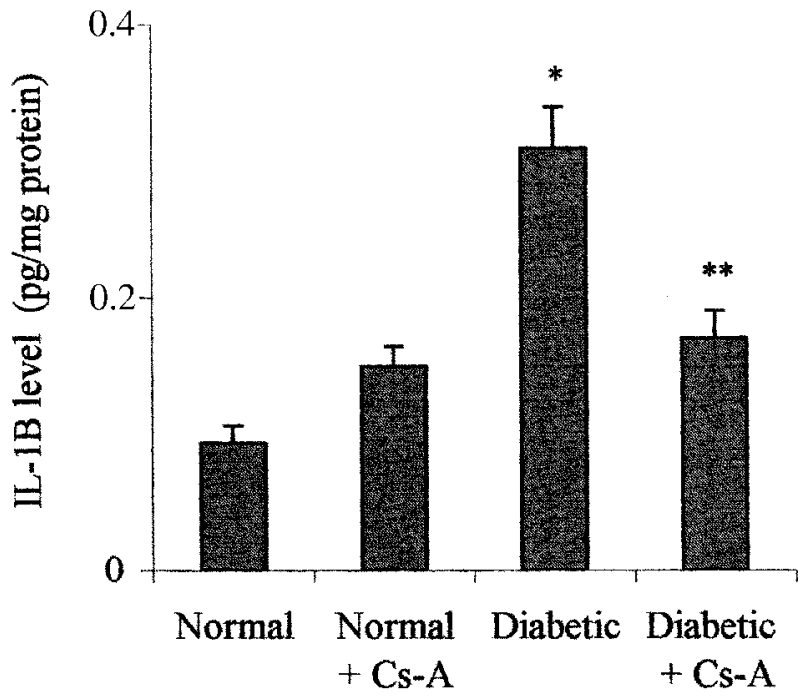

FIG. 1. Level of IL-1 $\beta$ in retina. The levels of IL-1 $1 \beta$ were determined in retinal lysates according to the kit instructions. Data are mean \pm SD values from 5 rats from each group. *Significant differences from normal rats. **Significant differences from Cs-A non-treated diabetic rats $(p>0.05)$ (oneway ANOVA analysis, Dunnett's test).

IL-1 $\beta$ did not differ significantly between the CsA-treated and non-treated normal rats.

\section{Effect of Cs-A on nitric oxide synthase activity}

The activity of NOS in retinal lysates was evaluated by the conversion of $\mathrm{L}-\left[{ }^{3} \mathrm{H}\right]$-arginine to $\mathrm{L}-\left[{ }^{3} \mathrm{H}\right]$-citrulline. As indicated in Fig. 2, in Cs-A-treated diabetic rats the production of $\mathrm{L}-\left[{ }^{3} \mathrm{H}\right]$-citrulline was significantly reduced $(175 \pm 19.5 \mathrm{pmol}$ L-citrulline $/ \mathrm{mg}$ protein/

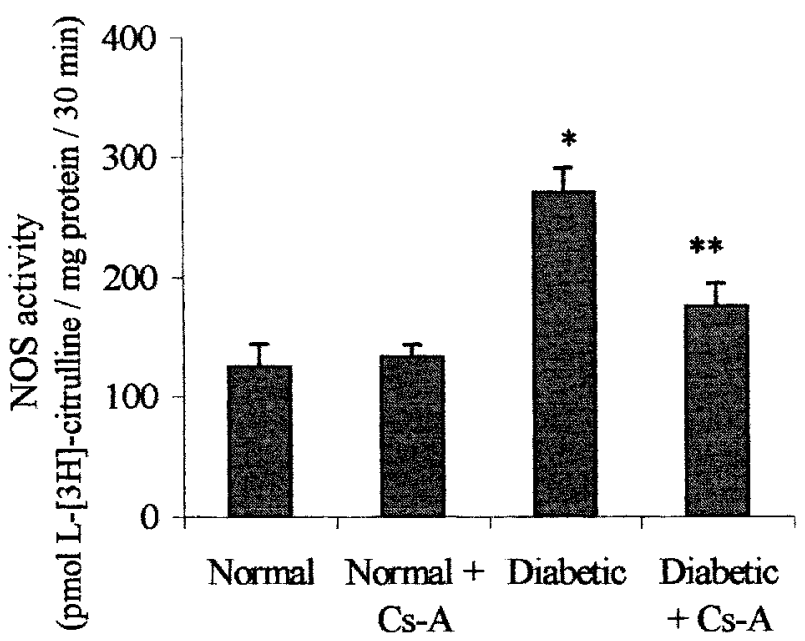

FIG. 2. Measurements of NOS activity in retina. Retinal lysates $(0.5 \mathrm{mg}$ protein $/ \mathrm{ml})$ were incubated in a medium containing $1 \mathrm{mMEGTA}, 0.5 \mathrm{mM}$ NADPH and $10 \mathrm{nM} \mathrm{L}-\left[{ }^{3} \mathrm{H}\right]$-arginine in the presence or absence of $2 \mathrm{mM} \mathrm{Ca}^{2+}$, in a total volume of $200 \mu \mathrm{l}$. The NOS activity was measured by the formation of L- $\left[{ }^{3} \mathrm{H}\right]-$ citrulline. Data are mean \pm SD values from 5 rats from each group. *Significant differences from normal rats. ** Significant differences from Cs-A non-treated diabetic rats $(p<0.05)$ (one-way ANOVA analysis, Dunnett's test). 
$30 \mathrm{~min})$ compared to that in non-treated diabetic rats $(270 \pm 215 \mathrm{pmol} \quad$ L-citrulline $/ \mathrm{mg}$ protein $/ 30 \mathrm{~min})$, $p<0.05$. The production of $\mathrm{L}-\left[{ }^{3} \mathrm{H}\right]$-citrulline did not differ significantly between the Cs-A-treated and nontreated normal rats.

\section{Effect of Cs-A on iNOS expression}

To determine whether Cs-A reduces NOS activity by inhibiting iNOS expression we examined the amount of iNOS protein content by Western blot analysis in retinal lysates (Fig. 3) and the localization of iNOS protein by imunohistochemistry in retinal sections.

As indicated in Fig. 3A, the Western blot analysis showed that in retinas from Cs-A-treated diabetic rats (Fig. 3A, Lane 4) the amount of iNOS protein $(130.6 \mathrm{kDa})$ decreased compared to that in retinas from Cs-A non-treated diabetic rats (Fig. 3A, Lane 3). Similar amounts of iNOS protein were detected in both treated and non-treated Cs-A normal rats (Fig. $3 \mathrm{~A}$, Lanes 1 and 2). These results indicate that in retinas from normal rats iNOS protein is constitutively expressed. As indicated in Fig. 3B the densitometric analysis revealed a significant decrease of iNOS protein content in retinas from Cs-A-treated diabetic
$\mathbf{A}$

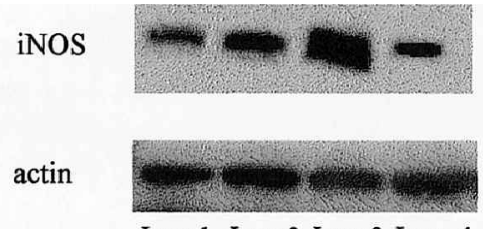

Lane 1 Lane 2 Lane 3 Lane 4
$130.6 \mathrm{kDa}$

$42 \mathrm{kDa}$

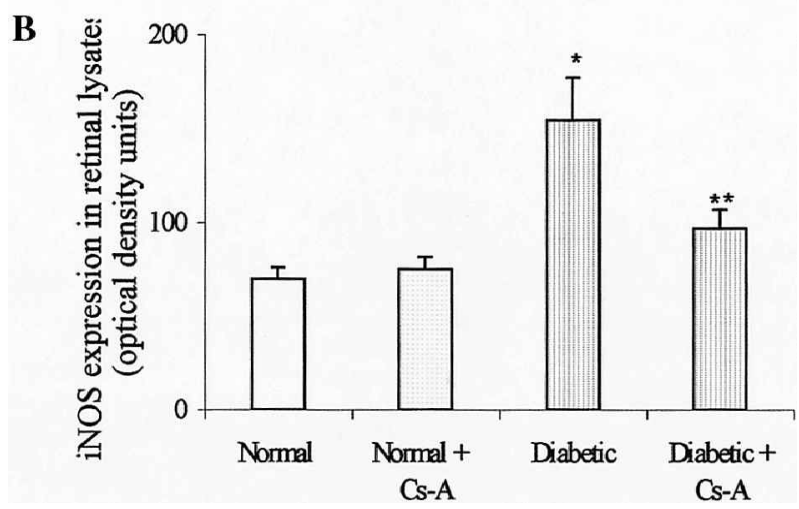

FIG. 3. Study of the expression of iNOS protein. (A) Western blot for detection of iNOS protein expression in retina. Retinal lysates were subjected to electrophoresis followed by immunoblotting with a polyclonal antibody against iNOS. Lane 1: retinal lysate from normal rats; Lane 2: retinal lysate from Cs-A treated normal rats; Lane 3: retinal lysate from diabetic rats; Lane 4: retinal lysate from diabetic rats. This figure is representative of 5 identical experiments. (B) Densitometric analysis of iNOS expression. Anti-actin was used to ensure that the protein loading was equivalent. Data are mean $\pm S D$ values from 5 rats from each group. *Significant differences from normal rats. **Significant differences from Cs-A non-treated diabetic rats $(p<0.05)$ (one-way ANOVA analysis, Dunnett's test).

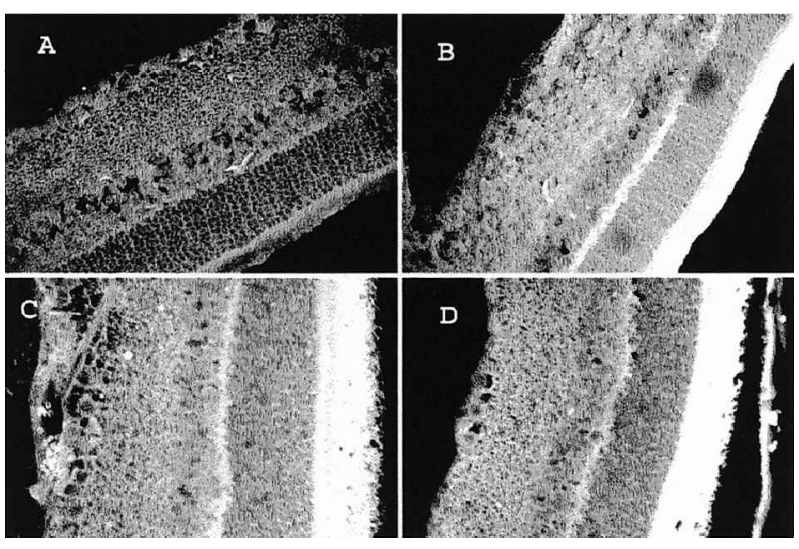

FIG. 4. Immunohistochemical localization of iNOS in intact retina. Retinal sections from normal and diabetic rats were incubated with the same anti-iNOS antibody used for the Western blot analysis. In control experiments retinal sections were only incubated with the secondary antibody. (A) retinal section from normal rats; (B) retinal section from CsA-treated normal rats; (C) retinal section from diabetic rats; (D) retinal section from Cs-A-treated diabetic rats. Magnification $20 x$.

rats $(154.45 \pm 22.8$ optical density) compared to that in retinas from Cs-A non-treated diabetic rats $(96.0 \pm 10.5$ optical density), $p<0.05$.

The immunolocalization of iNOS showed that in non-treated Cs-A diabetic rats, iNOS protein was clearly detected in the outer nuclear layer, inner nuclear layer, inner plexiform layer and also at the ganglion cell layer (Fig. 4C). In Cs-A-treated diabetic rats (Fig. 4D), iNOS protein remained localized at the inner nuclear and at the ganglion layer although the number of cells stained for iNOS in both retinal cell layers decreased compared to that in Cs-A non-treated diabetic rats. In retinas from Cs-A treated and nontreated normal rats iNOS protein was slightly expressed at the inner nuclear layer which explains the reduced amount of iNOS protein detected by Western blot (Fig. 4A, B).

\section{Effect of Cs-A on COX-2 expression}

To determine whether Cs-A reduces the expression of COX-2 protein we evaluated the amount of COX-2 protein by Western blot (Fig. 5). The results revealed that in retinas from Cs-A-treated diabetic rats (Fig. $5 \mathrm{~A}$, Lane 4) the amount of COX-2 protein decreased compared to that in retinas from Cs-A non-treated diabetic rats, (Fig. 5A, Lane 3). Similar amounts of COX-2 protein were detected in treated and nontreated Cs-A normal rats (Fig. 5A, Lanes 1 and 2). The data from the densitometric analysis of the blots confirmed that in Cs-A-treated diabetic rats there was a significant decrease (103.5 \pm 9.7 optical density) in COX-2 protein content compared to that in retinal lysates from Cs-A non-treated diabetic rats (143.7 \pm 16.4 optical density), $p<0.05$, Fig. 5B. 
A

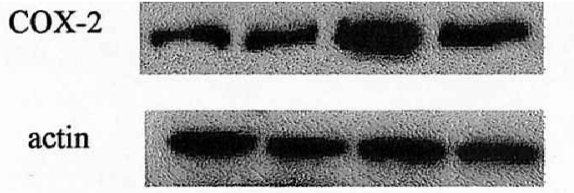

$72 \mathrm{kDa}$

Lane 1 Lane 2 Lane 3 Lane 4
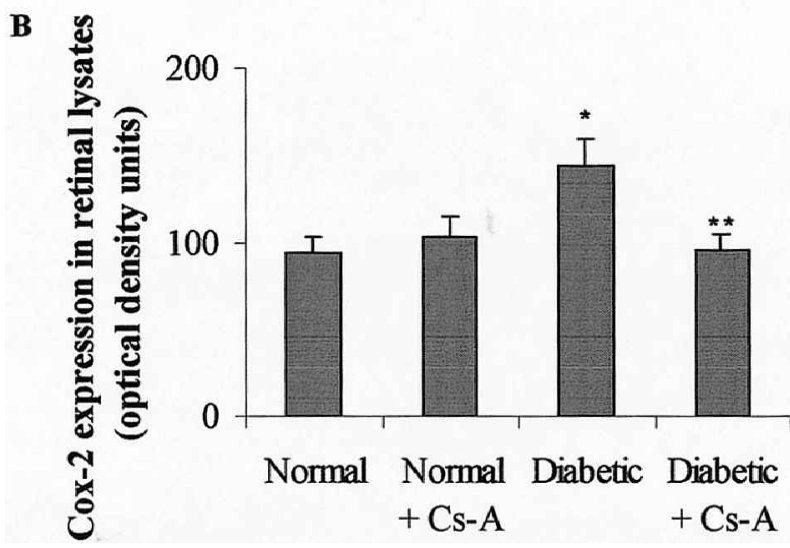

FIG. 5. Study of the expression of COX-2 protein. (A) Western blot for detection of COX-2 protein expression in retina. Lane 1: retinal lysate from normal rats; Lane 2: retinal lysate from Cs-A-treated normal rats; Lane 3: retinal lysate from diabetic rats; Lane 4: retinal lysate from diabetic rats. This figure is representative of 5 identical experiments. (B) Densitometric analysis of COX-2 expression. Anti-actin was used to ensure that the protein loading was equivalent. Data are mean \pm SD values from 5 rats from each group. *Significant differences from normal rats. ${ }^{*}$ Significant differences from Cs-A nontreated diabetic rats $(p<0.05)$ (one-way ANOVA analysis, Dunnett's test).

\section{Effect of Cs-A on BRB permeability}

In Cs-A non-treated diabetic rats there was a significant increase in vitreous protein concentration $(3.10 \pm 0.28 \mathrm{mg} / \mathrm{ml}$ of vitreous protein) compared to that in Cs-A non-treated normal rats $(1.1 \pm 0.17 \mathrm{mg} / \mathrm{ml}$ of vitreous protein), $p<0.01$ (Fig. 6). These results indicated that in Cs-A non-treated diabetic rats the permeability of BRB is significantly increased.

Cs-A-treated diabetic rats showed a significant decrease in vitreous protein concentration $(1.31 \pm$ $0.17 \mathrm{mg} / \mathrm{ml}$ of vitreous protein) compared to that in Cs-A non-treated diabetic rats $(3.10 \pm 0.28 \mathrm{mg} / \mathrm{ml}$ of vitreous protein), $p<0.01$ (Fig. 5), which indicated that Cs-A reduces the BRB permeability in diabetic rats.

\section{Discussion}

In our previous studies, we observed that there was a breakdown of the BRB in STZ-induced diabetic rats which appeared to be correlated with an increased level of NO and IL-1 $\beta$ in retinas from STZ-induced diabetic rats. ${ }^{4-6}$ In this study, we investigate whether the inhibition of IL-1 $\beta$ synthesis by Cs-A affects the expression of iNOS and COX-2 proteins, and we correlate those results with the BRB permeability.

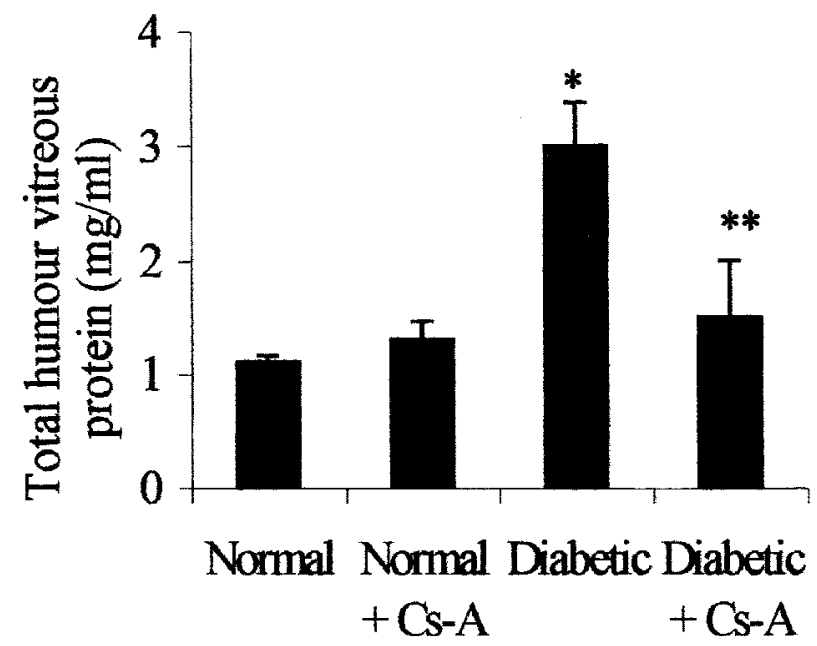

FIG. 6. Vitreous protein concentration. The protein concentration was determined according to the kit instructions. Data are mean $\pm S D$ values from 5 rats from each group. *Significant differences from normal rats $(p<0.05) .{ }^{*}$ Significant differences from Cs-A non-treated diabetic rats $(p<0.05)$ (one-way ANOVA analysis, Dunnett's test).

Cs-A reduced the level of IL-1 $\beta$ in retinas from CsA-treated diabetic rats. This result is in agreement with previous studies reporting that Cs-A inhibits IL-1 $\beta$ synthesis either in vitro, such as in rat renal mesanglial cells ${ }^{15}$ or in vivo as evaluated in atymic rats. ${ }^{12}$

The treatment of STZ-induced diabetic rats with CsA significantly reduced the NO production in retinas, which seemed to be associated with a decreased expression of iNOS protein. Other studies report that in mesanglial cells, Cs-A inhibits the IL-1 $\beta$-dependent transcriptional up-regulation of the iNOS gene by inhibiting the activation of the transcription factor NF-kB. ${ }^{15}$ Therefore, the decreased production of NO in retinas from Cs-A-treated diabetic rats, as indicated in Fig. 2, may be due to the inhibition of the cellular mechanism that controls the expression and the activity of iNOS.

We have previously observed that in eight-days STZinduced diabetic rats the main alteration of the BRB permeability was localized at the retinal vessels and that the iNOS protein was mainly expressed at the inner nuclear layer. ${ }^{4,16}$ Since the treatment of diabetic rats reduces the expression of iNOS protein which is accompanied by a significant reduction of the BRB permeability, it appears that the increased production of NO around the retinal vessels may affect retinal vessel permeability.

The COX-2 protein level in retinas from diabetic rats non-treated with Cs-A is increased compared to that in normal rats whereas in retinas from diabetic rats treated with Cs-A it is significantly reduced (Fig. 5). These results are in agreement with previous studies reporting that the expression of COX-2 could be induced by the cytokine IL- $1 \beta$ and by $\mathrm{NO}^{17,18}$ and that in rat mesanglial cells, IL-1 $\beta$-induced COX-2 expression was suppressed by Cs-A. ${ }^{19}$ The up-regulation of COX-2 
expression leads to an increased production of prostaglandins, which may act as vasodilatory and inflammatory mediators. ${ }^{20,21}$ Therefore, in the animal model of diabetes used in this work, COX-2 protein expression together with increased production of $\mathrm{NO}$ may be involved in the BRB breakdown.

Cs-A decreases the vitreous protein concentration in diabetic rats compared to that in diabetic rats nontreated with Cs-A (Fig. 6), which indicates that Cs-A causes a reduction of the BRB permeability.

In conclusion, the results from our study indicate that Cs-A reduces the BRB permeability in STZinduced diabetic rats. The effect of Cs-A in the BRB permeability appears to be related to a downregulation of pro-inflammatory cytokines IL-1 $\beta$ and $\mathrm{NO}$ as well as to the down-regulation of the expression of iNOS and COX-2 proteins.

ACKNOWLEDGEMENTS. The authors would like to thank Sandoz and ABBOT for kindly providing Cs-A and the kit for quantification of Cs-A, respectively and Dr Artur Paiva (Centro de Histocompatibilidade do Centro, Coimbra, Portugal) for technical assistance. This work was supported by Funda ão para a Ciência e Tecnologia, PRAXIS/SAU/14120/98.

\section{References}

1. Cunha-Vaz JG, Faria de Abreu J, Campos A, Figo G. Early breakdown of the blood-retinal barrier in diabetes. Br. J. Ophthalmol. 1975; 59: 649-56.

2. Bamforth SD, Lightman SL, Greenwood J. Ultrastructural analysis of interleukin-1 $\beta$-induced leukocyte recruitment to the rat retina. Invest. Opbthalmol. Vis. Sci. 1996; 38: 25-35.

3. Vinores SA, Niel EV, Swerdloff JS, Campochiaro PA. Electron microscopic immunocytochemical evidence for the mechanism of blood-retinal barrier breakdown in galactosemic rats and its association with aldose reductase expression and inhibition. Exp Eye Res 1993; 57: 723-35.

4. Carmo A, Ramos P, Reis A, Proen a R, Cunha-Vaz JG. Breakdown of the inner and outer retinal barrier in streptozotocin-induced diabetes. $\operatorname{Exp}$ Eye Res 1998; 67: 569-75.

5. Carmo A, Lopes C, Santos M, Proen a R, Cunha-Vaz JG, Carvalho, AP Nitric oxide synthase activity and L-arginine metabolism in the retinas from streptozotocin-induced diabetic rats. Gen. Pharmacol. 1998; 30(3): 319-24
6. Carmo A, Cunha-Vaz JG, Carvalho AP, Lopes MC. L-arginine transport in retinas from streptozotocin diabetic rats: correlation with the level of IL$1 \beta$ and NO synthase activity. Vis Res 1999; 39(23): 3817-23.

7. Carmo A, Cunha-Vaz, JG, Carvalho AP, Lopes MC. Study of NO production and BRB permeability in diabetic rats. Fund Clin Pharmacol 1999; 13(1): 171s

8. Welsh M, Welsh N, Bendtzen K, Mares J, Strandell E, Öberg C, Sandler S. Comparison of mRNA contents of interleukin $1 \beta$ and nitric oxide synthase in pancraetic islets isolated from female and male nonobese diabetic mice. Diabetologia 1995; 38: 153-60.

9. Rabinovitch A, Suarez-Pinzon W. Cytokines and their roles in pancreatic islet $\beta$-cell destruction and insulin-dependent diabetes mellitus. Biochem. Pharmacol. 1998; 55: 1139-49.

10. Claudio L, Martiney J, Brosnan CF. Ultrastructural studies of the bloodretina barrier after exposure to interleukin- $1 \beta$ or tumor necrosis factor- $\alpha$. Lab Invest 1994; 70: 850-61.

11. Bone A, Walker R, Varey A, Cooke A, Baird J. Effect of cyclosporin on pancreatic events and development of diabetes in BB/Edinburgh rats. Diabetes 1990; 39: 508-14.

12. Dawson J, Hurtenbach U, Mackenzie A. Cyclosporin A inhibits the in vivo production of interleukin $1 \beta$ and tumour necrosis factor $\alpha$, but not interleukin-6, by a T-cell-independent mechanism. Cytokine 1996; 8: 882-8.

13. Berkowitz BA, Roberto KA, Penn JS. The vitreous protein concentration is increased prior to neovascularization in experimental ROP. Current Eye Res 1998; 17: 218-21.

14. Lipman R, Epstein R, Hendricks R. Suppression of corneal neovascularization with cyclosporine. Arch. Ophthalmol. 1992; 110: 405-7.

15. Kunz D, Walker G, Eberhardt W, Nitsch D, Pfeilschifter J. Interleukin-1 $\beta$ induced exptression of nitric oxide synthase in rat renal mesanglial cells is suppressed by cyclosporin A. Biochem Biophys. Res. Commun. 1995; 216: $438-46$.

16. Carmo A, Cunha-Vaz JG, Carvalho AP, Lopes MC. Blood-retinal barrier permeability in streptozotocin-induced diabetic rats and goto-kakizaki rats. Invest. Ophthalmol. Vis. Sci. 2000; 41: 4.

17. McDaniel ML, Kwon G, Hill JR, Marshall CA, Corbett JA. Cytokines and nitric oxide in islet inflammation and diabetes. Proc. Soc. Exp. Biol. Med. 1996; 211: 24-32

18. Tetsuka T, Baier L, Morrison A. Antioxidants inhibit interleukin-1-induced cyclooxygenase and nitric oxide synthase expression in rat mesanglial cells. J Biol Chem 1996; 271: 11689-93.

19. Martin M, Neumann D, Hoff T, Resch K, DeWitt D, Goppelt-Struebe M. Interleukin-1-induced cyclooxygenase 2 expression is suppressed by cyclosporin A in rat mesanglial cells. Kidney Int 1994; 45: 150-8.

20. Mandrup-Poulsen T. The role of interleukin-1 in the pathogenesis of IDDM. Diabetologia 1996; 39: 1005-29.

21. Sjöholm A. Aspects of the involvement of interleukin-1 and nitric oxide in the pathogenesis of insulin-dependent diabetes mellitus. Cell Death Different 1998; 5: 461-468.

\section{Received 6 September 2000; accepted 6 October 2000}




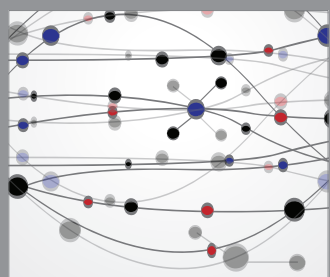

The Scientific World Journal
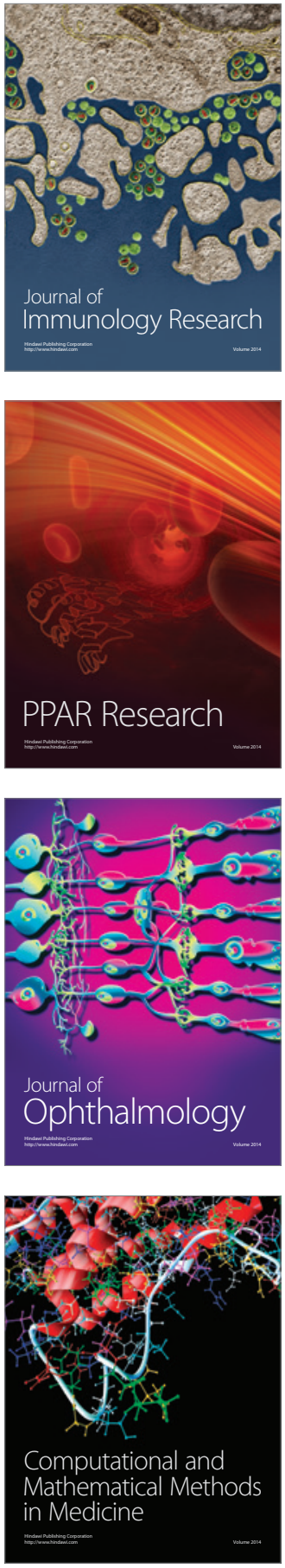

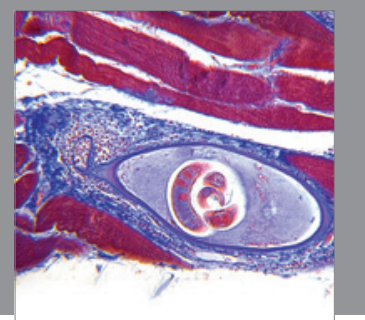

Gastroenterology

Research and Practice
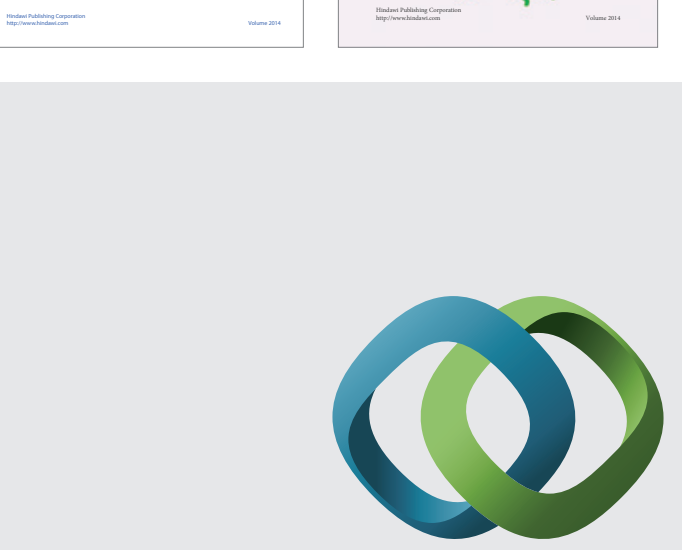

\section{Hindawi}

Submit your manuscripts at

http://www.hindawi.com
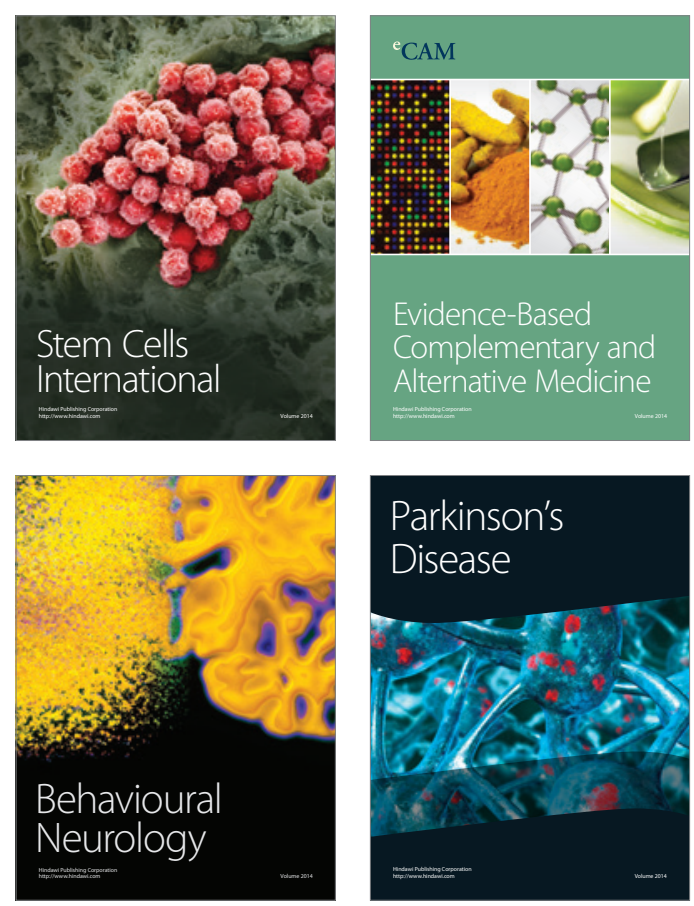

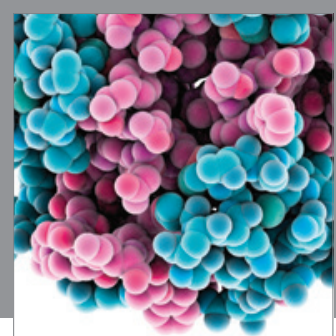

Journal of
Diabetes Research

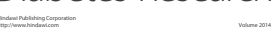

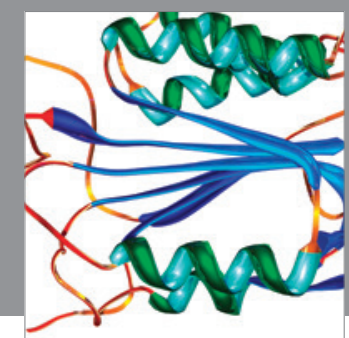

Disease Markers
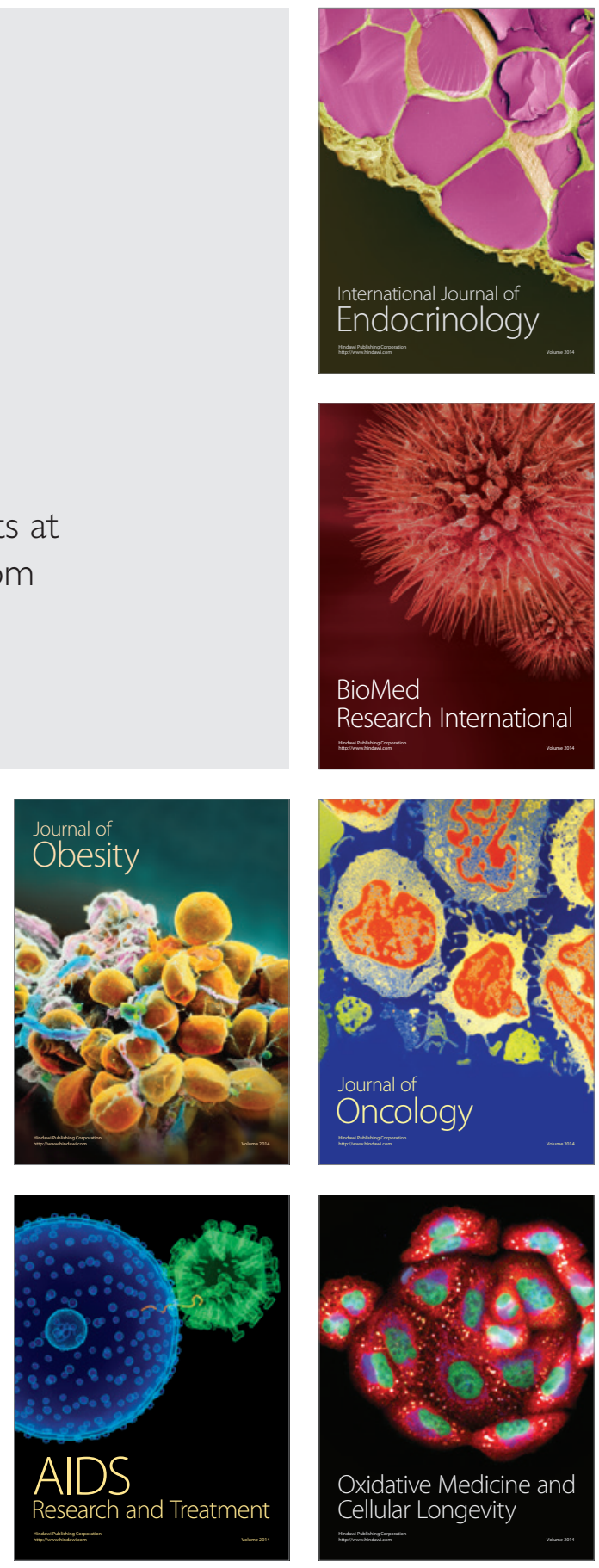